\title{
Recent Trends in Road Traffic Accident Parameters in Nigeria
}

\author{
O. S. Akpoghomeh \\ Department of Geography, University of Port Harcourt, Port Har court, Nigeria
}

\begin{abstract}
This study aims at examining the nature of the rising trends in road traffic accident phenomenon in Nigeria, using data for the period 1990 - 1995. It examines the spatio-temporal variations of road traffic accident parameters, in addition to studying the fatality (severity) and injury indices as well as the health risk for each state, and the country in general. The paper observes a downward trend in all road traffic accident parameters, with fatal and serious cases declining as much as $33 \%$ and $24 \%$ respectively, although, the number of person killed during the period experienced an increase. Regionally, the performance varied among the states of the country, with Lagos, Ogun, Niger, Edo, Kano, Kogi, Delta, Jigawa, Sokoto, Cross-River States and Abuja (Federal Capital Territory) recording high trends in all cases. These states thus need some more attention from all the agents of road safety in the country. The study concludes that, in addition to the behavioural modification approach which has not been emphasized enough, a lot more still needs to be done in such areas as maintenance of road transport infrastructure, vehicle road worthiness inspection, driver retraining and potential driver training, pedestrian education proper accident data collection, recording, storage and retrieval and finally law enforcement.
\end{abstract}

\section{Introduction}

The most serious problem facing road transportation today all over the world is the incident of road traffic accident (RTA). At the moment, it constitutes the most serious problem to traffic and personal safety on the highways. In Nigeria, the incident has become a very disturbing phenomenon and the country is presently ranked among the world's highest. Although road traffic accidents 
are completely inevitable, the fact that it is a leading cause of death and injury makes it a cause for serious concern to all countries.

Various researches in the country have noted a steady rise in all the parameters of road traffic accidents and offences (Onakomaiya, 1978, 1988, 1991, 1992; Bolade, 1991; Ogunsanya, 1991; Ovuworie, 1991 and Akpoghomeh, 1992). This was in spite of the efforts by the federal and state governments as well as government parastatals and the private sector to arrest the rising trend.

Several approaches and efforts have been employed to make the roads in Nigeria safer. The most commonly used methods are the behavioural modification approach which includes enforcement, education and propaganda. These methods were introduced as programme options for modifying the behaviour of road users. The various institutions which are in one way or the other responsible for road safety in Nigeria include the Vehicle Inspection Unit of the Federal Ministry of Works, the Federal Ministry of Transport, the Motor Traffic Division of the Nigeria Police, the Supply and Transport unit of the Nigerian Army, the Federal Road Safety Commission which was specifically set up by Decree 45 of 1988 to address the problem and which was recently merged with the Nigeria Police Force. These institutions have, at one time or the other, embarked on measures aimed at inculcating inculcate road safety consciousness on road users. Other organizations include the multinational companies, especially those in the oil sector, for example, Shell Petroleum Development Company (SPDC) 'Nigeria and the Nigerian National Petroleum Company (NNPC).

The Federal Road Safety Commission in particular has adopted such measures as enforcement of the traffic rules by arresting and prosecuting traffic offenders; educating the young ones to appreciate and adopt good road safety manners through taking part in the activities of Road Safety Clubs; public enlightenment and propaganda through advertisement on radio, television and newspaper; as well as rallies at motor parks, organized drama, stickers, etc. The Commission also introduced a revised Highway Code and uniform driving license. In spite of all the above, the progress so far achieved by the Federal Road Safety Commission has been attributed to public enlightenment programme. There is, however, no doubt that much still needs to be done, especially in the area of highway improvement and management as well as vehicle standard inspection and maintenance (Ogunsanya, 1991; Aikhomu, 1991).

Be that as it may, the effectiveness of all the measures so far adopted towards curbing the urgly trend in the country remains an open question. It is, therefore, necessary to examine the nature of the rising trend in the road traffic accident phenomenon in the country and suggest additional measures that will 
lead to the reduction of the wanton destruction of lives and properties on the country's roads via road traffic accidents.

This paper, therefore, examines the spatio-temporal trend of road traffic accident parameters in Nigeria using data for the period 1990-1995. It considered, among other things, the fatality or severity index, injury index and health risk for all the states and the country in general. The paper ends with a critical examination of the current efforts towards safer roads and makes recommendations that could complement existing efforts.

Data for study were collected from secondary sources which included publications of the Federal Office of Statistics, National Population Commission, the Nigeria Police Force and the Federal Road Safety Commission.

\section{The RTA Phenomenon}

Road traffic accident has emerged the single greatest source of death throughout the world. The world record had been estimated as half a million road traffic accidents annually and a projected figure of one million by the year 1995 (Trinca et al, 1988). The highways all over the world thus amount to a very serious risk to its users.

Ribbens (1992) compared the accident figures and accident rates in the mideighties for the different countries in Southern Africa and observed that accident rates in the region at that time varied between about 25 and 125 fatalities per 10,000 registered vehicles. However, later accident records available for some of the countries in the region suggested a deterioration of the situation. Malawi had the highest 'fatality rate' with a total of 200 persons killed every year per 10,000 registered vehicles while Zimbabwe recorded 32. However, Malawi had the lowest health risk, with about 9 persons killed pei 100,000 inhabitants each year, while Swaziland had the highest with 24 person; (Smak, 1992).

The situation in Nigeria has been outlined from the mid-1960s to the late 1980s by Onakomaiya (Onakomaiya, 1977, 1978, 1988, 1991 and 1992 and a high and increasing trend was established for all the RTA parameters When compared to situations in other parts of the world, the trend in Nigeria i very disturbing. For instance, while RTA in the country was as high as 14.4: per thousand vehicles, it was about 0.3 for North America and 0.5 for Wester Europe at about the same time. This makes the Nigerian record as high a twenty times those of Europe and North America. The phenomenon in th country in the 1980s was far worse than it was in Europe and North America i 1930, and worse than in India, Pakistan, Thailand, Botswana, Niger, Kenya, S Lanka in 1980 (Onakomaiya, 1991). By 1988, Nigeria topped the list of 3 countries world wide with the highest records of death by road accident 
(Aikhomu, 1988). On its impact on the economy, the phenomenon took 2 percent of the nations Gross Domestic Product (GDP) and 10 percent of the actual contribution of the transport sector to the GDP (Odedokun, 1991; Daily Champion, 1993).

The trend in the country could be likened to the pre 1940 automobile period in Europe when the increase in both the actual numbers and relative proportions of road accidents and fatalities outstripped the growth rate in traffic intensity. The Nigerian situation has been hinged on the fact that the rate of the development and enforcement in road traffic accident precautionary measures was far below the country's rate of motorization (Ogunsanya, 1991). The issue of road safety thus needs to be constantly re-examined as the country's level of motorization improves.

\section{Recent Trends in Nigeria}

In line with the aim of this study, which is to examine the trend in RTA parameters during the first half of the last decade of the last millennium, data were collected from 1990 to 1995 and these are shown in Table 1. The year 1992 emerged as the worst year, having recorded the highest RTA cases, the highest number of serious and fatal cases, as well as the highest number of persons injured. The Table shows that a total of 121,237 cases were reported during the period, thus giving an annual average of 20,206 cases and a daily average of 55. The above statistics manifest a decline when compared to the 1977/ 86 annual and daily averages of 32,040 and 88 reported cases respectively (Table 2).

This downward trend characterized all the RTA data, with fatal and serious cases declining by as much as 33 percent and 24 percent respectively. Of interest to this study is that, in spite of the general decline that characterized RTA parameters, the most critical parameter - the number of persons killed -experienced an increase. By way of explaining this observation, this paper argues tentatively that the general downward trend in the total number of RTAs and most of the other parameters may not have been necessarily due to the effort of the various law enforcement agent but most probably due to the down-turn in the country's economy which culminated in the introduction of the Structural Adjustment Programme (SAP) in 1986. The down turn in the economy alone made it extremely difficult for Nigerians to buy new cars and the introduction of SAP worsened the situation because car prices went beyond the reach of most Nigerians. Consequently, only few persons were, and are still, able to buy new cars or even the imported second hand cars. The implication of this on vehicular traffic is that the number of vehicles on our roads gradually declined, and this may have been mostly responsible for the observed decline in the total number of road traffic accident in the country in 
general. If this argument is sustained, then one way to minimize accident on our roads is to reduce the number of motor vehicles on the roads. This can be deliberately achieved by, among other ways, introducing an efficient and effective mass transit transport system and encouraging car owners to use them.

Road traffic accidents resulted in the death of a total number of 41,515 persons between 1991 and 1995, giving an average of 8301 deaths every year and 23 every day. This was a decline over the 1977-1986 period when an average of 7653 persons were killed annually (Table 2). Data also showed that an average of one death was recorded in every three accidents, while 5 lives were lost in every three fatal accidents. More people were killed in 1993 than ,in any other year under study.

An average of 8174 serious road traffic accidents (accidents in which at least one person was injured) was reported annually between 1990 and 1995 (Table 1). Compared to previous periods, this manifested a decline. This downward trend has been attributed more to the poor economy than to any other factor. However, 1992 had the highest case, while 1995 recorded the lowest. An average of 20,696 persons was injured every year, implying that 57 persons were injured every day in the country as a result of RTA. This is, however, an improvement on the 1977-1986 figure of 70. However, when the number of persons injured per accident (2:3) and the number of persons injured per serious accident (3:1) are considered, the trend calls for concern.

It is pertinent to note that other RTA parameters were not encouraging either. For instance, when compared to the $1977 / 86$ period, the study perioc experienced increases in the number of RTA per 1,000 vehicles recorded, the number of persons killed per 1,000 vehicles (Table 3 ) and in the fatality of severity indices. In addition, the Health Risk for the nation, measured by tb number of persons killed in RTA per 100,000 population for the period (11.3) was also higher than that for the 1982-86 period (7.8). There was, however, decline in the injury index. These trends highlighted above are ominous sign for road safety in the country.

The same arguments for the reduction in the number of vehicles on tli road may be responsible for the observed increase in fatalities. This is becaus SAP made it difficult for most vehicle owners to maintain their vehicles due 1 rising costs of spare parts, low ability of passengers to pay cost-covering fan and other road-user fees and the molestation by the law enforcements. $A$ these end up reducing the earnings of the vehicle operators which, in tur affect the regular maintenance of the vehicle. The resulting reduced roa worthiness of these vehicles and frustration of the vehicle operators usual driving to 'meet-up' with the day's returns and drivers' share for-the day $\mathrm{m}$ be responsible for the increased fatalities.

It is pertinent to note that these figures could be higher, considering the fact that many road traffic accidents are not reported, especially most of to 
minor cases. Moreover, almost all the road traffic accident victims who die in hospital within the United Nations stipulated thirty (30) days from the date of the accident are usually not included in the police reports. This has been associated with ignorance, difficulties in extracting such records from the hospital as a result of improper record keeping and apathy on the part of the law enforcement agents.

\section{Spatial Trend}

The largest percentage (48\%) of RTA was recorded in the South Western part of the country (including Kwara State). This represented an 8.6\% drop over the 1970/75 figure (Table 4). The North recorded the highest percentage of fatalities, having accounted for almost half of the fatalities in the country between 1992 and 1995. Although the region consistently recorded the lowest in the two parameters, it, however, experienced an increased growth rate in both parameters. The North recorded an increased growth rate in 'fatalities while it declined in the South West. The study observes that there seems to be no particular pattern between area and population of each region and the parameters.

Although the road traffic accident trend was generally on the decline in the country, this was not so for all the states of the country. States that recorded increases include Lagos, Delta, Yobe, Oyo and Kaduna States. In Lagos, for example, the number of reported cases state increased from 2,201 in 1982 to 2,551 in 1986 and to 3199 in 1995, representing 45 percent increase over the 1982 figure. During the period under study, the state recorded the highest annual average of 3113 cases and so maintained its unenviable lead in RTA cases in the country (Table 5). Other states with high annual averages include Edo, Ogun, Kano, Delta, Kaduna and Oyo states. These states accounted for almost 50 percent of RTA in the country annually.

The number of RTAs was compared with the total population of each state. For better comparison, the RTA case per 100,000 populations for each state was computed and the result is graphically presented in Figure 1. It shows that Lagos, Ogun and Edo states (as well as Abuja, FCT) are the states to watch. Other states include Delta and Cross Rivers. Road traffic accidents in these states, therefore, call for concern and, consequently, more efforts should be made in enforcing road safety regulations in these states if any meaningful success is to be achieved in the current efforts geared towards reducing the carnage on the country's roads now and in the future.

The sections which follow focus on the spatial aspects of the other parameters of RTA. All calculations were based on reported cases only. It is important to note this because since most minor accidents are usually not reported, the values of the indices calculated are likely to be exaggerated. 


\section{RTA Indices}

\section{Fatality}

Although fatalities declined from 8602 persons killed in RTA in 1992 to 6185 in 1995 , an annual average of 8301 was recorded, representing an increase of about 6.0 percent over the 1977/86 average (see Table 1). The spatial variation of this parameter across the 30 states and the Federal Capital Territory. Abuja (FCT) is shown in Table 6. This Table shows that Lagos recorded the highest number of fatal accidents as well as the highest number of fatalities. Other high-ranking states for both parameters (number of fatal accidents and fatalities) include Kano, Ogun, Niger, Kaduna and Edo States. These states accounted for almost $40 \%$ of the variation in each parameter.

\section{Fatality/Severity Index}

An important measure of the severity of road traffic accidents is IItfatality or severity index, usually measured by the number of persons killed per thousand accidents. This is represented as:

Fatality/Severity Index $=\frac{1,000 \mathrm{x}(\mathrm{f})}{\mathrm{y}}$

Where $\mathrm{x}(\mathrm{f})=$ total number of persons killed in RTA. $\mathrm{Y}=$ total RTA cases. For Nigeria: Total number of persons killed in RTA (4 year average) $=\mathrm{x}(0 ; 8228$ (col. 7 of Table 5)

Total no. of RTA cases, $y=19713$ (col. 5)

$\therefore$ Fatality/Severity Index for Nigeria

$$
=\frac{8228 \times 1,000}{19713}=417
$$

This figure further confirms that this index has been on the increase in t country since after independence. In 1971, the national average was 1 (Onakomaiya, 1981) and by 1985 the figure doubled, having hit 312 perse per 1,000 accidents (Onakomaiya, 1991) and in 1995 the figure had averaj 417 persons. The 1985 figure would probably have doubled in 1995 if economy did not suffer a set back. If this is accepted, it could be tentativ argued that the fatality/severity index for this country doubles in about e $\backslash$ fifteen years. Thus, if this trend continues without a check, by the year 2 (the country's vision year) the number of persons killed per 1,000 accid would have hit a ratio 1:1. In other words 1,000 persons shall be killed in $\mathrm{e}^{1} 1,000$ accidents cases. This obviously will be very grave for the nation whole.

For the states, take the case of Lagos State, for example: 
Total number of persons killed in RTA $x(f)$ (Lagos) $=800$ (col. 7 of Table 5)

Total number of in RTA cases y(Lagos) $=3113$ (col. 5 Table 5)

$\therefore$ Fatality/Severity Index for Lagos State

$$
=\frac{800 \times 1,000}{3113}=257
$$

Table 6 shows the spatial variation of the RTA parameters among the states of the country. Although this study has tentatively forecasted that about 1,000 persons may be killed in every 1,000 accidents ( 1 death per accident) by the year 2010'if the present trend is not reversed, it is pertinent to note that by 1995 some states of the Federation had almost approximated this projected national mean. Such states include Sokoto (886) and Jigawa (862). Other states with fatality/severity index above the national mean include Niger (832), Kog| (770), Plateau (640), Yobe (692), Taraba (679), Katsina (614), Bauchi (632) and Kwara (514). Notice that virtually all the states are located in the North (see also Table 3). At the other extreme, the states with the lowest indices were Lagos, Dejta and Edo. In spite of the high number of total accidents and, fatalities recorded by Lagos since the seventies, it has continued to record declining fatality index since then. According to Onakomaiya (1991), this persistently low index for Lagos state from 1970 is attributable to the relatively high level of traffic congestion which has continued to worsen with increased level of urbanization and population growth. This reduces the probability of accidents resulting fiom over speeding. Moreover, the fact that it has the easiest accessibility to post-crash medical care in the metropolitan area is an added factor.

\section{Probability of a Fatal Accident}

However, in the event of a road traffic accident, the chances of being involved in a fatal accident (that is, an accident in which at least a life is lost) are shown in Table 6, Column 3. The index is the proportion of the total accidents reported accounted for by the number of fatal accidents. This is represented by:

Fatal accident probability $=$

$$
\frac{x(f) \times 100}{y}
$$

For Nigeria:

Total number of fatal RTA cases, $x(f)=4913$ (col. 6 Table 5)

Total no. of RTA cases, $y,=19713$ (col. 5 Table 5)

$\therefore$ Probability of a fatal accident in Nigeria

$$
=\frac{4913 \times 100}{19713}=25 \%
$$


This implies that one out of every four accidents reported in the country will involve loss of life.

For the states, e.g. Lagos State:

Probability $=\frac{618 \times 100}{3113}=19.9 \%$

Table 6 shows the variation by states. Notice that this index was very high for some states like Kogi, Niger and Taraba where 1 out every 2 accident could be fatal.

These, indices are likely to be exaggerated due to non-reporting of most minor cases which would have increased the total number of RTA and eventually reduce the value of the indices calculated.

\section{Serious Accidents}

For the benefit of doubt, a serious accident is one in which bodily harm was suffered. The variation in number of serious accident cases among the states is shown in Tables 5 and 6. The data show that Lagos State topped the list, followed by Edo and Ogun States. At the other extreme are Abuja, Jigawa and Yobe States. Regionally, most of the states with figures above the national mean are located in the South-western part of the country.

Although the nation recorded a decline in the number of persons injured when compared to the $1970 / 75$ period, an average of 20,574 persons were injured in RTA in the country every year between 1992 and 1995; this approximates to over 56 per day. More that a quarter (26\%) of these were involved in RTA in Lagos, Ogun, Edo and Kano States.

A more meaningful picture of the phenomenon is shown when the number of persons injured is compared with the total number of accident cases (injury index), and the total number of serious RTA cases (probability of being injured in a serious RTA). These are calculated and analyzed below.

\section{Injury Index}

The injury index is a measure of the number of persons injured per F,000 accidents reported. This is represented by the formula:

\section{Injury Index $=\underline{\mathrm{x}(\mathrm{j}) \mathrm{x} 1.000}$ \\ $\mathrm{y}$}

where $x(j)=$ total number of injured persons.

$\mathrm{y}=$ total number of RTA cases

For Nigeria:

Total number injured, $x(j)=20574$ (Table 6) 
Total number of RTA reported, $\mathrm{y}=19713$

$$
\therefore \text { Injury Index }=\frac{20574 \times 1,000}{19713} \quad=1043.7
$$

This index for the nation implies that in every RTA reported in the country, at least one person gets injured. With an injury index of about 1,044 the country experienced an increase in the number of persons who suffered bodily harm as a result of road traffic accidents over the years. Some of these may have resulted in permanent disability or death eventually.

For the states, e.g. Lagos State

Injury Index $=\frac{1851 \times 1,000}{3113}=594.6$

Table 6 shows the injury index for the period 1992-95 for the states. Kogi State recorded an alarming injury index of 2,640, implying that for every road traffic accident in that state, almost 3 persons suffered bodily harm. This is, however, not very surprising because of the nodal nature of the State for North-bound traffic from the South-East and South-South axis. Most of these RTA may involve through-traffic, since most of the traffic from the southern parts of the country and heading for the northern parts of the country pass through the states. As a matter of fact, the fatality and seriousness of road traffic accidents involving coaches (luxury buses), mini and midi buses, especially on the inter-state highways, have been disturbing in the recent past. Other high-ranking states include Jigawa, Sokoto, Abuja, Bauchi, Katsina, Niger, Taraba, and Yobe. Notice that all are located in the northern parts of the country. States with the lowest injury index include Ondo, Lagos and Anambra.

\section{Probability of being involved in a Serious Accident}

This probability was measured by the number of serious road traffic accident cases per total road traffic accident cases, and is represented as

Serious accident probability $=\frac{\mathrm{x}(\mathrm{f}) \times 100}{\mathrm{y}}$

For Nigeria, it is:

$$
\underline{7979 \times 100}=40.5
$$

19713

For the states, e.g. Lagos State, it is: $\underline{1292 \times 100}=41.5$ 
The above results imply that, in the event of a RTA in Nigeria, the probability that the accident may result in bodily harm was about $40.5 \%$ in 1995 . This probability was higher in some states like Cross River, Akwa Ibom Delta, Imo and Abia, where each RTA had at least about a 50 percent chance of resulting in injuries (Table 6, col. 4). The probability was lowest for Kogi, Niger, Kwara and Jigawa States.

As earlier noted, the actual probability could be far lower than what is obtained in all the indices above due to gross under-reporting of minor accidents in the country. It is an obvious fact that most minor accidents are not reported in Nigeria because most motorists think the encumbrances and time wasting involved, if quantified, are more that the cost of taking care of vehicular damages. Where the damages are very minor, the motorists do not ever think of reporting the incident to the police. Although this practice is not proper, the average motorist believes that that is a better option than going to the police because of the bureaucratic delays and other experiences with the law enforcement agents.

\section{Health Risk}

An important traffic accident index is the Health Risk. This is computed by the number of persons killed in RTA per 100,000 population.

$$
\begin{aligned}
\text { Health Risk } & =\frac{\mathrm{nx} 100,000}{\mathrm{P}} \\
\text { Where } \mathrm{n} & =\text { total number of persons killed in RTA. } \\
\mathrm{p} & =\text { total population. This was the }
\end{aligned}
$$

projected 1991 population figure for 1995. The projection put the Nigeria population at more than 99 million persons (Federal Government of Nigeria, 1997)

$$
\begin{aligned}
& \text { Health Risk for the country was } \\
& \frac{8228 \times 100,000}{99.200 .000}=8.3
\end{aligned}
$$

For Lagos State, as an example of a Nigerian state

$$
\text { Health Risk is: } \quad \frac{800 \times 100,000}{6,682,000} \quad \text { which is: } 12.0
$$

Table 6 shows the variation of this index among states of the federation. With a Health Risk 8.3 in 1995, the study period manifested an increase of about 30 percent over the 1970/75 index of 6.4 (Onakomaiya, 1991). Notice that some states recorded Health Risks that are more than twice that of the nation. These states include Abuja, Ogun, Niger and Edo States. Other high-ranking states include Kogi, Kwara, Cross Rivers, Osun and Lagos Sates. Notice also that the high-ranking states are aligned generally in the South-West/North-Central axis. 
This spatial pattern may have been influenced by the Trans Saharan Highway which runs from Lagos through Ibadan and Oyo (in Oyo State); Ilorin and Jebba (in Kwara State) Kotangora (in Niger State); Sabo Birnin Gwari, Kaduna and Zaria (in Kaduna State); Kano and Kazaure (in Kano State) and to Konogolam (in Katsina State). The route is a major highway that links the south-western parts of the country in particular with the northern parts of the country through the North-Central. The route is also linked with the South-East, via Edo and Kogi States.

The increasing trend for this index (6.4 for 1970-75; 7.8 for 1986, and 8.3 for 199295 ) casts doubt on the effectiveness of the various road safety efforts by the government, including the Federal Road Safety Commission and the Police, as well as some private organizations and individuals, in reducing the carnage on the country's roads. A lot more, therefore, needs to be done to reverse the ugly trend.

\section{Observations and Recommendations}

The approaches to inculcating road safety consciousness in motorists in Nigeria have been through road safety campaigns, radio/television jingles and propaganda and, of course, arrests and prosecution of offenders. It is obvious from this paper that the behavioural modification approaches have not been very successful. It is against this background that this paper advocates that, in addition to the existing approaches, there is need to also focus on a more critical aspect of road safety but yet seriously undermined by the various levels of government and their various law enforcement agents, especially in the last decade. This is the management as well as improvement of transport infrastructure. It is obvious to all that this aspect of road safety has been neglected in the last two decades. As a matter of fact, road transport infrastructure, over these years, have collapsed and deteriorated sometimes beyond repairs. Most of our roads became death traps while road signs to warn motorists of such dangers were not in place. Law enforcement agents themselves became agents of traffic accidents with road works at the most-inauspicious points on the high ways. To this end, this paper hereby makes the following observations and recommendations

\section{Road Survey and Maintenance:}

It is no gain saying that Nigerian roads have been death traps, especially in the last two decades. This was due to the complete negligence and lack of maintenance of the roads. Large pot-holes are known to exist right at the center of some of the highways, while some others are riddled with pot holes. Gully erosion in some cases has almost cut roads into two, and such cases remain without maintenance for months. In some other cases, some of the roads are 
rendered impassable, especially during the rainy season. Bad bridges are not left out in the no-maintenance culture of the country. These road hazards have been responsible for very ghastly and serious road traffic accidents, especially because unsuspecting motorists are usually not forewarned by appropriate road signs.

In the light of this, the various agencies responsible for safety on the country's roads should regularly carry out surveys and inspection of the roads to identify damages to the roads and report the same to the agency responsible for carrying out repairs on the roads. Meanwhile, such pot holes (black spots) should be identified and marked out to serve as advance warning signs to road users.

\section{Law Enforcement:}

The present traffic law enforcement is slow and ineffective. This has been associated with inadequate manpower; lack of control equipment, like radar, blood analyzer, communication equipment, and poor training and retraining schemes. To correct this shortcoming, it is hereby recommended that the manpower of the various road safety agencies should be increased to meet their levels of need. In addition, adequate and efficient equipment such as blood analyzers, the right patrol vehicle, ambulances, good and modern communication gadgets should be provided for them. Moreover, better training should be given to fresh employees, while those already in employment are retrained on a regular basis not only in traffic enforcement but. also in public relations.

\section{Accident Recording and Statistics:}

Data and statistics on road traffic accident are essential and necessary components of road safety planning. Very unfortunately, however, these are poorly organized in the country. The accident reporting practice of the police, who are the main source of road traffic accident data, only gives a fairly detailed record of individual accidents. Consequently, the accident data and statistics, as are presently collected, recorded and stored, do not contain all the necessary elements needed in the planning of road safety.

The Police and its Federal Road Safety Unit should collect, record and store, in easily retrievable form, data that are more detailed. For instance, in addition to what already exists, information should include:

- The location of the accident: This will indicate the spot on the road, using the nearest milestone; it will also indicate the distance from the nearest intersection; types of intersection; nature of the road at the point of crash, that is, straight road or on a bend, pot holes etc. 
Road characteristics: This will indicate the type of road, (whether rural or-urban); multiple lanes, dual carriage' or two-lane road; whether the road is divided or undivided, etc.

Local weather conditions as at the time of crash: This, will indicate whether it was rainy, sunny, foggy or hazy; the temperature, time of day, period of day morning, afternoon, or night, etc.

Vehicle: numbers of vehicles involved, type and make of vehicle(s) colour(s) of the vehicle(s); passenger capacity and the number of persons in the vehicle(s); ownership, etc.

Restraints: whether vehicle has seat belt; whether driver and other occupants were wearing seat belt, etc.

Fatality: This will include the condition of the driver, total number of persons killed on the spot and within the United Nations stipulated 30 days, the number of persons injured, seat location of those killed/injured, and possible cause of death.

Origin-destination data.

Socio-economic data of those killed or injured and

Types and values of major items destroyed.

The Police's road accident data as they are today are completely devoid of these details.

\section{Driver Education:}

The driver has been identified as the most important single factor in road traffic accidents. Thus, the proper training of drivers and effective licensing procedures are two critical prerequisites for the production of high quality drivers. The existing driving schools in Nigeria are too few and lack adequate, appropriate and efficient equipment and infrastructure. There is need, therefore, to encourage the establishment of more and better-equipped government-approved driving schools. To enforce compulsory attendance of these schools by potential drivers and drivers alike, a certification of proficiency issued by such schools should be a precondition to qualify for consideration for granting and renewal of driving licenses.

\section{Motor Vehicle Testing:}

Traffic safety also depends on the safety and general standards of the vehicles. Consequently, a thorough and strict check on all vehicles for road-worthiness is essential; this is highly recommended for public passenger vehicles, especially those for masstransit It is note worthy that the Lagos State Government has started something in this direction in the new millennium, but its sustainability is another question. 


\section{Highway Patrol:}

The Federal Highway Patrol, the Police and its Federal Safety Unit should regularly patrol the Trunk-A roads which have bad road traffic accident records. Such roads include the Lagos-Ibadan Express Way, the Ibadan-IIorin-Abuja-Kaduna-Kano Road, the BeninSagamu Road and the Benin-Asaba-Onitsha-Owerri-Aba Road. These are major roads running through the states with high road traffic accident rate. Very importantly, during patrol, emphasis should shift from the checking of vehicle particulars to the checking of the driving habit of motorists and passing on to them useful information on the road condition and situation.

\section{Summary and Conclusion}

The paper has highlighted the recent trends in the spatial variation of RTA parameters in Nigeria. Although the performance varied among states, some states had very bad records. Among these states, Lagos, Ogun, Niger, Edo, Kano, Kogi, Delta, Jigawa, Sokoto Cross River and Abuja (FCT) need special attention. More efforts towards road safety enforcement should be intensified in these states in particular if any positive and meaningful results are to be achieved in the country in general. Recently, the Federal Road Safety Unit within the Nigeria Police promised to embark on intensive patrols on the highways in Ogun and Niger states. Road clinics have also been proposed for RTA victims in these states. A lot more still needs to be specifically done in the area of maintenance of road transport infrastructure, vehicle road-worthiness inspection, driver retraining and potential driver-training, pedestrian education, proper accident data collection, recording and storage and law enforcement.

The measures for checking the rising carnage on the country's roads are not exhaustive. However, if the measures enumerated in this paper, in addition to the behavioural modification approaches currently adopted by the various road safety agencies in the country, are vigorously pursued, especially in those states and highways with very bad road traffic accident records, there is no doubt that the rising trend in the road traffic accident and its parameters will be reduced.

\section{References}

Akpoghomeh, O. S. (1992) 'Spatio-Temporal Analysis of Road Traffic Accidents in Nigeria' (Paper presented at the Abuja International Conference on Road Safety Experience and Practice in Africa, Abuja, Nigeria 26th - 29/h October).

Bolade, T. (1991) The Highway Risk Problem In Nigeria' in Accident Control and Safety Measures in Mass Transit Operations in Nigeria Bolade, T. and A. A. Ogunsanya (eds) Ibadan: Ibadan University Press: 1-10. 
Recent Trends in Road Traffic Accident Parameters in Nigeria 81

Daily Champion, (1993) 'Shonekan Worried Over Road Accident,' Monday, Feb. , 22, p. 9.

Federal Republic of Nigeria (1987) Digest of Statistics, Federal Office of Statistics, Lagos, Nigeria.

Federal Republic of Nigeria (1998) Annual Abstracts of Statistics. Federal Office of Statistics, Lagos, Nigeria, p. 95.

Federal Republic of Nigeria (1994) Digest of Statistics. Federal Office of Statistics, Lagos, December.

Federal Republic of Nigeria (1996) Annual Abstract of Statistics. Federal Office of Statistics, Abuja.

Federal Republic of Nigeria (1997) The 1991 Population Census Figures. National Population Commission, Abuja.

Odedokun, M. O. (1991) 'Accident and Productivity Level in the Transport Industry' in Bolade, T. and A. Ogunsanya (eds.) Accident Control and Safety Measures in Mass Transit Operations in Nigeria, Ibadan: Ibadan University Press.

Ogunsanya A. A. (1991) 'Accident and Safety in Nigeria: The Way Ahead' in Bolade T.and A. Ogunsanya (eds) Accident Control and Safety Measures in Mass Transit Operation in Nigeria. Ibadan: Ibadan University Press: 257-262

Onakomaiya, S. O. (1977) 'Understanding Road Traffic Accidents in Nigeria: Some Preliminary Findings and Research Needs' in Onakomaiya, S. O. and N. F. Ekanem (eds.) Transportation in Nigerian Development. NISER: pp.445-489.

Onakomaiya, S. O. (1978) Spatio-Temporal Analysis of Road Accidents in Nigeria. flVt.Sc. Project. Department of Transportation and Environmental Planning, University of Birmingham, U. K.)

Onakomaiya S. O. (1988) Unsafe at Any Speed: Toward Road Transportation for Survival (Inaugural Lecture, Univrsity of Ilorin, Ilorin).

Onakomaiya S. 0. (1991) 'General Trend of Safety and Accident Records in the Nigerian Transport Sector' In Bolade T. and A. Ogunsanya (eds.) Accident Control and Safety Measures In Mass Transit Operation In Nigeria. Ibadan: Ibadan University Press, pp. 11-21.

Onakomaiya, S. O. (1992) 'Towards Effective Road Safety Research and Action Programmes.' (Paper Presented at Abuja Internationa! Conference on Road Safety Experience and Practice in Africa, Abuja Nigeria $26^{\text {th }}-29^{\text {th }}$ October)

Ovuworie, G. C. (1991) 'Causes of Accidents and General Preventive Measure" in Accident Control and Safety Measure in Mass Transit 
Operations in Nigeria Bolade, T. and A. A. Ogunsanya (eds) Ibadan: Ibadan University Press, Chapter 4

Ribbens, H. (1992) 'Road Traffic Safety Activities in Southern Africa'. (Paper Presented at the Abuja International Conference on road Safety Experience and Practice in Africa, Abuja, Nigeria, 26 $6^{\text {th }}-29^{\text {th }}$ October).

Smark, K. (1992) 'Road Safety Work in SADCC Members States in Southern African'. (A Paper Presented at the Abuja International Conference on Road Safety Experience and Practice in Africa, Abuja Nigeria, $26^{\text {th }}-29^{\text {th }}$ October).

Transport Canada (1989) Smashed, Ontario.

Transport Canada (1989) Canadian Motor Vehicle Traffic Accident Statistics. (Leaflet).

Trinca G. W. et al (1988) Reducing Traffic Injury: A Global Challenge. A. H. Massina $\&$ Co. Melbourne.

Table 1: Road Traffic Accident Trends 1990-1995

$\begin{array}{llllll}\text { Year } & \begin{array}{l}\text { Total } \\ \text { Accident } \\ \text { Injured }\end{array} & \begin{array}{l}\text { Serious } \\ \text { Cases } \\ \text { Killed }\end{array} & \begin{array}{l}\text { No. of } \\ \text { Persons }\end{array} & \begin{array}{l}\text { Faial } \\ \text { Cases }\end{array} & \begin{array}{l}\text { No. of } \\ \text { Persons }\end{array} \\ 1990 & 21,827 & 8855 & \text { n.a. } 6299 & \text { n.a } & \\ 1991 & 65,658 & 8285 & \text { n.a } 6513 & \text { n.a } & \\ 1992 & 22,496 & 9194 & 25,499 & 6820 & 9493 \\ 1993 & 21,612 & 8485 & 24,444 & 6819 & 9595 \\ 1994 & 18,523 & 7464 & 18,950 & 5755 & 7640 \\ 1995 & 15,729 & 6759 & 13,329 & 4,244 & 6185 \\ \text { Total } & \mathbf{1 6 5 , 8 4 5} & \mathbf{4 9 , 1 4 5} & \mathbf{8 0 , 6 7 6} & \mathbf{3 6 , 4 5 0} & \mathbf{3 2 , 9 1 3} \\ \text { Annual } & & & & & \\ & \mathbf{2 7 , 6 4 1} & \mathbf{8 1 9 1} & \mathbf{2 0 , 1 6 9} & \mathbf{6 0 7 5} & \mathbf{8 2 2 8} \\ \text { Average } & & & & & \end{array}$

Source: Federal Government Nigeria (1996) Annual Abstract of Statistics,, Federal Office of Statistics. 
Table 2: Inter-Period Comparison of RTA Parameters

\begin{tabular}{llllllr} 
Period & Total & Annual & Intera Period & Intera & Average & \multicolumn{1}{c}{ Average } \\
& Cases & Average & Growth Rate & $\begin{array}{l}\text { Period } \\
\text { Growth }\end{array}$ & $\begin{array}{c}\text { No. } \\
\text { Injured }\end{array}$ & \multicolumn{1}{c}{$\begin{array}{l}\text { Injured } \\
\text { Injually }\end{array}$} \\
& & & & Annually \\
$1977-1986$ & 320.400 & 32.040 & $-30 \%$ & - & 7653 & 26,096 \\
$1990-1995$ & 165.845 & 27.641 & $-28 \%$ & $-38 \%$ & 8228 & 20,169
\end{tabular}

Source: Federal Government Nigeria (1988) Annual abstract of Statistics ${ }^{\wedge}$ Federal office of Statistics. Lagos, p 95.

(1987), Digest of Statistics, Federal Office of Statistics, Lagos, Nigeria.

..(1996) Annual Abstracts of Statistics, Federal Office of Statistics, Abuja.

Table 3: Temporal Variation of RTA Parameters 1990 - 1995

$\begin{array}{lccccl}\text { Year } & \begin{array}{l}\text { Estimate of } \\ \text { Vehicle in } \\ \text { Use* }\end{array} & \begin{array}{l}\text { No.of } \\ \text { accident }\end{array} & \begin{array}{l}\text { No. of } \\ \text { Death }\end{array} & \begin{array}{c}\text { Accident } \\ \text { Per 1000 } \\ \text { Vehicles }\end{array} & \begin{array}{l}\text { Death Per } \\ 1000 \\ \text { Vehicles }\end{array} \\ 1990 & 367 & 21829 & - & 59.5 & - \\ 1991 & 331 & 65658 & - & 198.4 & - \\ 1992 & 298 & 22496 & 9493 & 75.5 & 6820 \\ 1993 & 268 & 21612 & 9595 & 80.6 & 35.8 \\ 1994 & 241 & 18523 & 7640 & 76.9 & 37.7 \\ 1995 & 217 & 15729 & 6185 & 72.5 & 28.5 \\ \text { Total } & & 165,845 & 32,913 & - & \\ \text { Annual } & 1990-1995 & 27,641 & 8228 & 93.9 & 33.4 \\ \text { Average } & 1971- & (30,007) & - & (61) & (15)\end{array}$

\section{Sources:}

1. Federal Republic of Nigeria, (1996) Annual Abstract of Statistics Federal Office of Statistics. 1996 Edition.

2. Federal Republic of Nigeria, (1994) Digest of Statistics, Federal Office of Statistics, Dec. 1994.

*Estimate assumed 10\% decrease as used by Onakomaiya. S. O(1991).

"Trends in Nigerian Road Safety \& Accident Situation" in Bolade T, and A. A.

Ogunsanya (eds.) (1991) Accident Control and Safety Measures in Mass Transit Operations in Nigeria, Ibadan University Press. 
84 Annals of the Social Science Academy of Nigeria, No. 12, January-December, 2000

Table 4

Percentage Distribution of Accidents and Fatalities 1970/75 $1988 / 86$ and $1992 / 95$

\begin{tabular}{|c|c|c|c|c|c|c|c|c|}
\hline \multirow[b]{3}{*}{ Region } & \multicolumn{6}{|c|}{ Average Annual Percentage } & \multicolumn{2}{|c|}{$\begin{array}{c}\text { Percentage Change } \\
\text { between } 1970 / 75 \text { and } \\
1992 / 95\end{array}$} \\
\hline & \multicolumn{3}{|c|}{ Accident } & \multicolumn{3}{|c|}{ Fatalities } & \multirow[b]{2}{*}{ Accident } & \multirow[b]{2}{*}{ Facilities } \\
\hline & $\begin{array}{c}1970 / \\
75\end{array}$ & $\begin{array}{c}1985 / \\
86\end{array}$ & $1992 / 95$ & $1970 / 75$ & $\begin{array}{c}1985 / \\
86\end{array}$ & $\begin{array}{c}1992 / \\
95\end{array}$ & & \\
\hline South West & 52.5 & 37.5 & 48,0 & 40.2 & 334 & 34.4 & -8.57 & -144. \\
\hline South East & 17.5 & 207 & 18.3 & 148 & 16.2 & 16.1 & +4.57 & +8.78 \\
\hline North & 400 & 41.5 & 33.7 & 450 & 49.8 & 49.5 & -15.75 & +10.0 \\
\hline $\begin{array}{l}\text { National } \\
\text { rowth Rate }\end{array}$ & & & & & & & -19.75 & +4.38 \\
\hline rowth Rate & & & & & & & & \\
\hline
\end{tabular}

Source: Figures for 1970/75 and 1985/86 were from Onakomaiya S. O. (1991)

"Trends in Nigeria Road Safety and Accident situation" In Bolade T. \& A Ogunsaniya (ed.) (1991), Accident Control and Safety Measures in Mas: Transit Operations in Nigeria. Ibadan University Press. P. 17. All other figures were computed from data.

Table 5: Variation of Road Traffic Accident (RTA) Trend in Nigeris

\begin{tabular}{|c|c|c|c|c|c|c|c|c|}
\hline No & State & $\begin{array}{c}\text { Area } \\
\text { Sq/KM }\end{array}$ & $\begin{array}{c}\text { Projected } \\
1995 \text { POP. } \\
\left({ }^{\circ} 000\right)\end{array}$ & $\begin{array}{c}\text { R.T.A } \\
\text { 4-Year } \\
\text { Average }\end{array}$ & $\begin{array}{l}\text { No of Fatal } \\
\text { Accident }\end{array}$ & $\begin{array}{l}\text { No. of } \\
\text { Persons } \\
\text { Killed }\end{array}$ & $\begin{array}{c}\text { No of } \\
\text { Serious } \\
\text { Accident }\end{array}$ & $\begin{array}{l}\text { No. of } \\
\text { Persons } \\
\text { Injured }\end{array}$ \\
\hline 1 & $\mathrm{ABIA}$ & 6,320 & 2,660 & 403 & 137 & 167 & 190 & 382 \\
\hline 2 & ADAMAWA & 36,917 & 2,662 & 322 & 120 & 137 & 152 & 396 \\
\hline 3 & AKWA IBOM & 7.081 & 2.725 & 482 & 166 & 187 & 248 & 437 \\
\hline 4 & ANAMBRA & 4.844 & 3.274 & 561 & 149 & 183 & 247 & 377 \\
\hline 5 & BAUCHI & 64.605 & 5,143 & 494 & 222 & 312 & 177 & 872 \\
\hline 6 & BENUE & 34.059 & 3.084 & 634 & 208 & 275 & 285 & 793 \\
\hline 7 & BORNO & 70.897 & 2,822 & 396 & 129 & 144 & 145 & 425 \\
\hline 8 & $\begin{array}{l}\text { CROSS } \\
\text { RIVER }\end{array}$ & 20,156 & 2.296 & 6221 & 170 & 230 & 319 & 607 \\
\hline 9 & DELTA & 17.698 & 2.957 & 1.012 & 217 & 280 & 499 & 826 \\
\hline 10 & EDO & 17.802 & 2.577 & 1.467 & 289 & 413 & 606 & 1,236 \\
\hline 11 & ENUGU & 12,831 & 3.520 & 567 & 167 & 218 & 236 & 511 \\
\hline 12 & IMO & 5.530 & 2,522 & 392 & 112 & 157 & 192 & 351 \\
\hline 13 & ЛGAWA & 23.154 & 3,165 & 159 & 82 & 137 & 56 & 382 \\
\hline 14 & KADUNA & 46,053 & 4.710 & 894 & 296 & 454 & 300 & 886 \\
\hline 15 & KANO & 20.131 & 7.544 & 1.141 & 350 & 498 & 423 & 1,044 \\
\hline 16 & KATSLNA & 24.192 & 4.276 & 329 & 132 & 202 & 136 & 501 \\
\hline 17 & KEBBI & 36.800 & 2.366 & 119 & 104 & 56 & 53 & 167 \\
\hline 18 & KOGI & 29.833 & 2.434 & 344 & 185 & 265 & 78 & 908 \\
\hline 19 & KWARA & 36.825 & 1.788 & 346 & 118 & 187 & 105 & 432 \\
\hline 20 & LAGOS & 3.345 & 6.682 & 3.113 & 618 & 800 & 1,292 & 1851 \\
\hline 21 & NIGER & 16.363 & 2,877 & 590 & 317 & 491 & 178 & 988 \\
\hline 22 & OGUN & 16.762 & 2.606 & 1.201 & 337 & 502 & 524 & 1,283 \\
\hline 23 & ONDO & 29,959 & 4.335 & 751 & 195 & 281 & 333 & 385 \\
\hline 24 & OSUN & 9.251 & 2.344 & 647 & 200 & 313 & 269 & 793 \\
\hline 25 & OYO & 28.454 & 3.703 & 953 & 250 & 360 & 310 & 650 \\
\hline 26 & PLATEAL & 58,030 & 3.827 & 464 & 221 & 297 & 144 & 601 \\
\hline 27 & RIVERS & 21.850 & 5.243 & 591 & 131 & 210 & 254 & 549 \\
\hline 28 & SOKOTO & 65.735 & 5,070 & 263 & 109 & 233 & 100 & 563 \\
\hline 29 & TARABA & 54.473 & 1.761 & 106 & 54 & 22 & 38 & 167 \\
\hline 30 & YOBE & 45.502 & 1.599 & 146 & 63 & 101 & 50 & 229 \\
\hline \multirow{3}{*}{31} & ABUIA & 7,315 & 470 & 204 & 65 & 92 & 46 & 372 \\
\hline & MEAN & 923.768 & 99,220 & 19.789 & 5.913 & 8.228 & 7,979 & 20,574 \\
\hline & MEDIAN & & & 638 & 191 & 265 & 257 & 664 \\
\hline
\end{tabular}

Source: Computed from data. 
Table 6:

RTA Indices for the States of Nigeria 1992 - 1995

\begin{tabular}{|c|c|c|c|c|c|c|c|}
\hline $\mathrm{S} / \mathrm{N}$ & , State & $\begin{array}{c}\text { Fatal Accident } \\
\text { Per Total } \\
\text { Accident }(\%)\end{array}$ & $\begin{array}{c}\text { Serious } \\
\text { Arcident Per } \\
\text { Total . Iccillent } \\
\text { ("io) }\end{array}$ & $\begin{array}{c}\text { Fatality of } \\
\text { Severity Index }\end{array}$ & $\begin{array}{l}\text { Injury } \\
\text { Index }\end{array}$ & $\begin{array}{c}\text { Health Risk } \\
\text { (Death/100,00 } \\
\text { O POP) }\end{array}$ & $\begin{array}{c}\text { RTA } \\
\text { Per100,000 } \\
\text { pop }\end{array}$ \\
\hline 1 & Abia & $3 ?:$ & 450 & 414 & 690 & 6.3 & 15.2 \\
\hline 2 & Adamawa & $8+11$ & 43.1 & 426 & 1230 & 5.2 & 12.1 \\
\hline 3 & Akwa lbom & $3+3$ & .500 & 388 & 907 & 6.9 & 17.6 \\
\hline 4 & Anambra & 25.9 & 42.9 & 326 & 672 & 5.6 & 17.1 \\
\hline 5 & Bauchi & 44.9 & 35.8 & 632 & 1765 & 6.1 & 9.6 \\
\hline 6 & Benue & 32.8 & 45.0 & 434 & 1254 & 8.9 & 20.6 \\
\hline 7 & Borno & 32.6 & 36.6 & 364 & 1073 & 5.1 & 14.0 \\
\hline 8 & Cross River & 27.4 & 51.4 & 370 & 978 & 10.0 & 27.1 \\
\hline 9 & Delta & 21.4 & 49.3 & 277 & 816 & 9.5 & 34.2 \\
\hline 10 & Edo & 19.7 & $41.3=$ & 282 & 843 & 16.0 & 56.9 \\
\hline 11 & Enugu & 29.5 & 41.6 & 385 & 901 & 6.2 & 16.1 \\
\hline 12 & Imo (Ebonyi) & 28.6 & 490 & 395 & 895 & 6.2 & 15.5 \\
\hline 13 & Jigawa & 44.6 & 30.4 & 862 & 2403 & 1.2 & 5.0 \\
\hline 14 & Kaduna & 33.1 & 33.6 & 508 & 991 & 9.6 & 19.0 \\
\hline 15 & Kano & 30.7 & 37.1 & 437 & 915 & 7.6 & 17.4 \\
\hline 16 & Katsina & 40.4 & 41.3 & 614 & 1523 & 4.7 & 7.7 \\
\hline 17 & Kebbi & 53.8 & 27.5 & 471 & 1403 & 2.4 & 5.0 \\
\hline 18 & Kogi & 54.4 & 22.9 & 770 & 2640 & 10.9 & 14.1 \\
\hline 19 & Kwara & 34.0 & 30.3 & 541 & 1220 & 10.5 & 19.4 \\
\hline 20 & Lagos & $19.1^{2}$ & 41.5 & 257 & 595 & 12.0 & 9.3 \\
\hline 21 & Niger & 53.7 & 30.2 & 832 & 1675 & 17.1 & 20.5 \\
\hline 22 & Ogun & 28.1 & 43.6 & 418 & 1068 & 193 & 46.1 \\
\hline 23 & Ondo & 26.0 & 44.3 & 374 & 513 & 6.5 & 17.3 \\
\hline 24 & Osun & 30.9 & 41.6 & 484 & 1226 & 13.4 & 27.6 \\
\hline 25 & Oyo & 26.2 & 32.5 & 378 & 892 & 9.7 & 25.7 \\
\hline 26 & Plateau & 46.6 & 31.0 & 640 & 1295 & 7.8 & 12.1 \\
\hline 27 & Rivers \& Bayelsa & 22.2 & 43.0 & 355 & 946 & 4.0 & 11.3 \\
\hline 28 & Sokoto & 41.5 & 38.0 & 886 & $2|4|$ & 4.6 & 5.2 \\
\hline 29 & Taraba & 50.9 & 35.9 & 679 & 1594 & 4.1 & 6.0 \\
\hline 30 & Yobe & 42.9 & 34.0 & 692 & 1569 & 6.3 & 6.6 \\
\hline \multirow[t]{3}{*}{31} & Abuja & 28.0 & 199 & 451 & 1824 & 43.4 & 196 \\
\hline & Mean & 30.0 & 40.8 & 454 & 1019 & 8.3 & 211 \\
\hline & Median & 327 & 413 & 436 & 1147 & 7.3 & 15.5 \\
\hline
\end{tabular}

Sources: Computed from date 